\title{
Article
}

\section{A Molten-Salt Pyrolysis Synthesis Strategy toward Sulfur-Functionalized Carbon for Elemental Mercury Removal from Coal-Combustion Flue Gas}

\author{
Jianping Yang ${ }^{1}$, Hong $\mathrm{Xu}^{1}{ }^{1}$, Fanyue Meng ${ }^{1}{ }^{(\mathbb{D}}$, Qingjie Guo ${ }^{2}$, Tao He ${ }^{3}$, Zequn Yang ${ }^{1}$, Wenqi Qu ${ }^{1}$ \\ and Hailong $\mathrm{Li}^{1}$,*
}

check for

updates

Citation: Yang, J.; Xu, H.; Meng, F.;

Guo, Q.; He, T.; Yang, Z.; Qu, W.; Li, H. A Molten-Salt Pyrolysis Synthesis Strategy toward Sulfur-Functionalized Carbon for Elemental Mercury Removal from Coal-Combustion Flue Gas. Energies 2022, 15, 1840. https:// doi.org/10.3390/en15051840

Academic Editors: Roberto Alonso González Lezcano, Francesco Nocera and Rosa Giuseppina Caponetto

Received: 29 January 2022

Accepted: 27 February 2022

Published: 2 March 2022

Publisher's Note: MDPI stays neutral with regard to jurisdictional claims in published maps and institutional affiliations.

Copyright: (C) 2022 by the authors. Licensee MDPI, Basel, Switzerland. This article is an open access article distributed under the terms and conditions of the Creative Commons Attribution (CC BY) license (https:// creativecommons.org/licenses/by/ $4.0 /)$.
1 School of Energy Science and Engineering, Central South University, Changsha 410083, China; jpyang@csu.edu.cn (J.Y.); xh18@foxmail.com (H.X.); mfy19941029@163.com (F.M.); zequn_yang@hotmail.com (Z.Y.); wenqiqu1984@163.com (W.Q.)

2 State Key Laboratory of High-Efficiency Utilization of Coal and Green Chemical Engineering, Ningxia University, Yinchuan 750021, China; qingjie_guo@nxu.edu.cn

3 Shandong Shiheng Thermal Power Co., Ltd., Taian 271600, China; hthetao1988@163.com

* Correspondence: hailongli18@gmail.com; Tel.: +86-18670016725; Fax: +86-731-88879863

\begin{abstract}
The emission of mercury from coal combustion has caused consequential hazards to the ecosystem. The key challenge to abating the mercury emission is to explore highly efficient adsorbents. Herein, sulfur-functionalized carbon (S-C) was synthesized by using a molten-salt pyrolysis strategy and employed for the removal of elemental mercury from coal-combustion flue gas. An ideal pore structure, which was favorable for the internal diffusion of the $\mathrm{Hg}^{0}$ molecule in carbon, was obtained by using a $\mathrm{SiO}_{2}$ hard template and adjusting the $\mathrm{HF}$ etching time. The as-prepared S-C with an HF etching time of $10 \mathrm{~h}$ possessed a saturation $\mathrm{Hg}^{0}$ adsorption capacity of $89.90 \mathrm{mg} \cdot \mathrm{g}^{-1}$, far exceeding that of the commercial sulfur-loaded activated carbons (S/C). The S-C can be applied at a wide temperature range of $25-125{ }^{\circ} \mathrm{C}$, far exceeding that of commercial S/C. The influence of flue gas components, such as $\mathrm{SO}_{2}, \mathrm{NO}$, and $\mathrm{H}_{2} \mathrm{O}$, on the $\mathrm{Hg}^{0}$ adsorption performance of S-C was insignificant, indicating a good applicability in real-world applications. The mechanism of the $\mathrm{Hg}^{0}$ removal by S-C was proposed, i.e., the reduced components, including sulfur thiophene, sulfoxide, and C-S, displayed a high affinity toward $\mathrm{Hg}^{0}$, which could guarantee the stable immobilization of $\mathrm{Hg}^{0}$ as $\mathrm{HgS}$ in the adsorbent. Thus, the molten-salt pyrolysis strategy has a broad prospect in the application of one-pot carbonization and functionalization sulfur-containing organic precursors as efficient adsorbents for $\mathrm{Hg}^{0}$.
\end{abstract}

Keywords: mercury; adsorption; carbon; molten salt; coal combustion

\section{Introduction}

The excessive emission of mercury from industrial activities has caused consequential hazards to the ecosystem and human health [1-3]. Coal combustion is one of the largest industrial sources of mercury emission. The mercury emitted from typical coal-combustion flue gas generally existed in three forms, i.e., elemental mercury $\left(\mathrm{Hg}^{0}\right)$, oxidized mercury $\left(\mathrm{Hg}^{2+}\right)$, and particulate bound mercury $\left(\mathrm{Hg}^{\mathrm{p}}\right)$ [4-8]. The $\mathrm{Hg}^{\mathrm{p}}$ can be captured by using particulate matter control devices, while the $\mathrm{Hg}^{2+}$ can be removed by using wet flue-gas scrubbers due to $\mathrm{Hg}^{2+\prime}$ s water solubility [9-12]. However, $\mathrm{Hg}^{0}$ is difficult to remove owing to its water insolubility and high volatility [13-15]. As a consequence, $\mathrm{Hg}^{0}$ is the primary species of mercury discharged into the atmosphere from coal-combustion flue gases. The highly efficient removal of $\mathrm{Hg}^{0}$ is a key challenge to reducing mercury pollution from coal-fired power plants.

Activated carbons (ACs) are the most widely researched and skilled mercury adsorbents for coal-fired power plants [16-21]. However, ACs were generally limited by 
adsorption kinetics and equilibrium capacities, hence causing large consumptions of ACs during $\mathrm{Hg}^{0}$ removal $[22,23]$. Moreover, the weak binding affinity of ACs toward mercury induced leaching risks of mercury when the ACs were dumped in landfills together with fly ashes $[24,25]$. Thus, active components that can accommodate $\mathrm{Hg}^{0}$ were generally introduced to the $\mathrm{ACs}$ to improve the $\mathrm{Hg}^{0}$ adsorption capacity. In nature, the mercury was tied to sulfides owing to its sulphophile affinity [26,27]. Inspired by this natural law, sulfur was widely employed to modify the $\mathrm{Hg}^{0}$ adsorption capacity of ACs $[28,29]$. This strategy was relatively simple, cheap, and effective, but was still found to suffer from drawbacks [30,31]. The most significant one is that the sulfur was not actually anchored to the carbon surface during the impregnation process, hence affecting the activity, abundance, and accessibility of the sulfur groups during $\mathrm{Hg}^{0}$ removals [32]. The impregnation method for introducing sulfur would plug the pores of ACs. As a result, the efficient diffusion of $\mathrm{Hg}^{0}$ on the sulfur-modified ACs would be limited [33]. In addition, the anchoring of sulfur on ACs was not firm, hence causing leaching risks of sulfur as well as mercury adsorption products when ACs were disposed of in landfills [32,34]. Therefore, a new strategy is urgently undergoing exploration to overcome the disadvantages associated with sulfur-impregnated ACs [35,36].

Traditionally, the sulfur-functionalized carbon materials were prepared by using two steps, i.e., the carbonization of natural products (e.g., cellulose, chitin, starch, alginic acid, and chitosan) as well as some synthetic polymers (e.g., poly-acrylonitrile, polyaniline, and phenolic resins) first and then introducing sulfur onto carbons by using an impregnation method [37-40]. A one-pot carbonization and functionalization step, which could guarantee the uniform distribution and firm fixation of sulfur functionality on the carbon matrix, was required. Very recently, a simple approach via the carbonization of small organic molecules with the assistance of transition metals was reported to prepare a series of functional carbon materials [37]. This approach was realized via the pyrolysis of a mixture of small organic molecules and transition-metal salts in a conventional tubular furnace, hence avoiding the barriers to large-scale production, such as complicated equipment and harsh conditions. The salts would act as a heat-transfer medium and provide an oxygen-free environment for pyrolysis [41]. Moreover, the salts catalyze the formation of a thermally stable intermediate polymerization structure, avoiding the direct sublimation of small organic molecules during heating $[37,38]$. More attractive, template-like $\mathrm{SiO}_{2}$ could be mixed into the precursors and hence adopted to adjust the porosity of carbons. This strategy is commonly available and easy to use to control the surface sulfur functionalities, porosities, and morphologies of carbons.

In this work, porous sulfur-functionalized carbons were prepared and employed for $\mathrm{Hg}^{0}$ removal from coal-fired flue gas. The removal performance of sulfur-functionalized carbon (S-C) on $\mathrm{Hg}^{0}$ was studied and compared with that of commercial sulfur-loaded ACs (S/C). The $\mathrm{Hg}^{0}$ removal performances of S-C and S/C under various adsorption temperatures and flue gas conditions were studied. The excellent adsorption mechanism of $\mathrm{Hg}^{0}$ by S-C was further investigated. This work not only provides a promising trap for highly efficient $\mathrm{Hg}^{0}$ sequestration from coal-fired power plants but also illustrates a versatile platform for preparing functional carbon materials by using a one-pot carbonization and functionalization organic precursor.

\section{Experimental Section}

\subsection{Sample Preparation}

S-C was prepared by using a molten-salt pyrolysis strategy [38]. Two grams of 2,2bithiophene and $2.0 \mathrm{~g}$ of $\mathrm{SiO}_{2}$ were added into $150 \mathrm{~mL}$ of tetrahydrofuran and stirred at room temperature for $6 \mathrm{~h}$. The mixture was then dried and then ground to a powder. After that, the powder was placed into a rail boat and covered with $5.0 \mathrm{~g}$ of $\mathrm{Co}\left(\mathrm{NO}_{3}\right)_{2} \cdot 6 \mathrm{H}_{2} \mathrm{O}$, which was heated at $800{ }^{\circ} \mathrm{C}$ for $2 \mathrm{~h}$. Then, the $\mathrm{SiO}_{2}$ was removed by using $10 \% \mathrm{HF}$ solution. To obtain different porosity of $\mathrm{S}-\mathrm{C}$, the sample was etched by using HF for different times $(0,24,48$ and $56 \mathrm{~h})$. After drying at $105^{\circ} \mathrm{C}$ for $10 \mathrm{~h}$, the S-C was finally obtained. 


\subsection{Sample Characterization}

The morphology of the sample was studied by using a scanning electronic microscope (SEM, FEI F50, New York, NY, USA). Transmission electron microscope (TEM, EOL JEM 2100F, microscope Tokyo, Japan) and high-resolution TEM (HRTEM) were used to study the morphology and structure of sample. The valence states of samples were characterized by using X-ray photoelectron spectroscopy (XPS, Thermo ESCALAB 250Xi, New York, NY, USA).

\section{3. $\mathrm{Hg}^{0}$ Adsorption Activity Tests}

The $\mathrm{Hg}^{0}$ adsorption activity test was measured on a fixed-bed reactor [42,43]. The adsorbent was placed in a quartz reactor, reaction temperature of which was controlled by using a tube furnace. The flue gas was composed of $\mathrm{N}_{2}, \mathrm{O}_{2}, \mathrm{SO}_{2}, \mathrm{NO}$, and $\mathrm{H}_{2} \mathrm{O}$, with the total flow rate of $1 \mathrm{~L} \cdot \mathrm{min}^{-1}$. $\mathrm{Hg}^{0}$ was provided by a mercury permeation tube placed in a constant temperature water bath, delivering $\mathrm{Hg}^{0}$ by using $\mathrm{N}_{2}$ to ensure a stable concentration of $65 \mu \mathrm{g} \cdot \mathrm{m}^{-3}$. The concentration of $\mathrm{Hg}^{0}$ was monitored by using an online mercury analyzer (RA-915M, Lumex, Tianjin, China). The $\mathrm{Hg}^{0}$ adsorption capability was calculated by using the following equations:

$$
Q=\frac{1}{m} \int_{t_{1}}^{t_{2}}\left(C_{\text {in }}-C_{\text {out }}\right) \times f \times d t
$$

where $C_{\text {in }}\left(\mu \mathrm{g} \cdot \mathrm{m}^{-3}\right)$ and $C_{\text {out }}\left(\mu \mathrm{g} \cdot \mathrm{m}^{-3}\right)$ represent the inlet and outlet concentrations of $\mathrm{Hg}^{0}$, $Q\left(\mu \mathrm{g} \cdot \mathrm{g}^{-1}\right)$ is the $\mathrm{Hg}^{0}$ adsorption capacity, $m(\mathrm{~g})$ is the sample amount, $f\left(\mathrm{~m}^{3} \cdot \mathrm{h}^{-1}\right)$ is the gas flow rate, and $t(\mathrm{~h})$ is the reaction time.

\section{Description of Sorption Kinetic Models}

\subsection{Pseudo-First-Order Model}

This model is described as follows [44]:

$$
\frac{d q_{t}}{d t}=k_{1}\left(q_{e}-q_{t}\right)
$$

Based on the initial conditions, i.e., $t=0 q_{t}=0$, Equation (2) is revised as:

$$
q_{t}=q_{e}\left(1-e^{-k_{1} t}\right)
$$

where $q_{t}$ and $q_{e}$ represent the adsorbed mercury amount at any time $t$ and equilibrium time $\left(\mu \mathrm{g} \cdot \mathrm{g}^{-1}\right) . k_{1}$ represents the rate constant $\left(\mathrm{min}^{-1}\right)$.

\subsection{Pseudo-Second-Order Model}

This model is described as follows [45]:

$$
\frac{d q_{t}}{d t}=k_{2}\left(q_{e}-q_{t}\right)^{2}
$$

On the basis of initial conditions, i.e., $t=0$ and $q_{t}=0$, Equation (4) is modified as:

$$
q_{t}=\frac{t}{\frac{1}{k_{2} q_{e}^{2}}+\frac{1}{q_{e}} t}
$$

where $k_{2}$ represents the rate constant $\left(\mu \mathrm{g} /\left(\mathrm{cm}^{3} \cdot \mathrm{min}\right)\right)$.

\subsection{Elovich Model}

This model is described as follows [46]:

$$
\frac{d q_{t}}{d t}=\alpha \exp \left(-\beta q_{t}\right)
$$


where $\alpha$ represents the initial rate and $\beta$ is related to surface coverage and activation energy. If $t$ is much larger than $t_{0}$, this equation is modified as follows:

$$
q_{t}=\frac{1}{\beta} \ln (\alpha \beta)+\left(\frac{1}{\beta}\right) \ln t
$$

\subsection{Intra-Particle Diffusion Model}

This model is described by the following formula [47]:

$$
q_{t}=k_{i d} t^{0.5}+C
$$

where $k_{i d}$ represents the diffusion rate constant within the particle and $C$ is a constant, which is related to the boundary layer.

\section{Results and Discussion}

\subsection{Preparation and Characterization of Samples}

The S-C was prepared by using the molten $\mathrm{Co}\left(\mathrm{NO}_{3}\right)_{2} \cdot 6 \mathrm{H}_{2} \mathrm{O}$-assisted carbonization of sulfur-containing small organic molecule precursors. $\mathrm{SiO}_{2}$ nanoparticles were adopted as hard templates, followed by an $\mathrm{HF}$ etching step to remove the $\mathrm{SiO}_{2}$ template. The porosity of S-C was adjusted by using the HF etching time (shown in Figure 1). As listed in Table 1, the HF etching step will generate mesopores on the S-C. The S-C with HF etching for $10 \mathrm{~h}$ possessed the largest BET surface area of $318.5 \mathrm{~m}^{2} \cdot \mathrm{g}^{-1}$, with an average pore size of $7.31 \mathrm{~nm}$ and total pore volume of $0.58 \mathrm{~cm}^{3} \cdot \mathrm{g}^{-1}$. Pore size affects the internal mass transfer process of $\mathrm{Hg}^{0}$ on adsorbents, thus affecting the removal rate of $\mathrm{Hg}^{0}$. As shown in Figure 2a, the $\mathrm{N}_{2}$ absorption-desorption isotherms for S-C belonged to a typical II isotherm, indicating that the porosity of S-C was very limited. The S-C after the HF etching step presented a typical IV isotherm with a negligible absorption at lower pressures but significant absorption at higher pressures $\left(\mathrm{p} / \mathrm{p}^{0}=0.2-1.0\right)$. This indicates that $\mathrm{S}-\mathrm{C}$ is composed of mesopores or macropores rather than micropores. The pore distribution curves shown in Figure $2 b$ demonstrate that the pore size of the S-C was in the range of $2-10 \mathrm{~nm}$. The mesoporous structure in the range of 2-50 nm is beneficial for $\mathrm{Hg}^{0}$ 's diffusion to the inner surface of an adsorbent [48]. Thus, the pore structure of S-C is favorable for $\mathrm{Hg}^{0}$ adsorption.
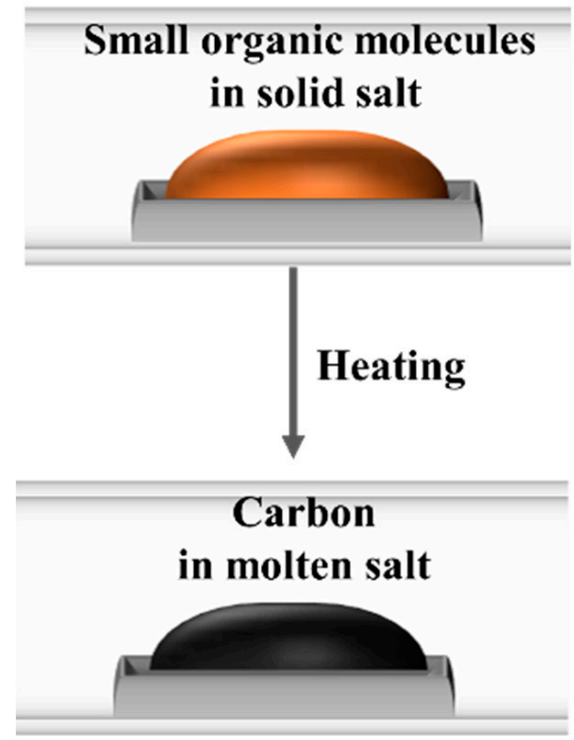

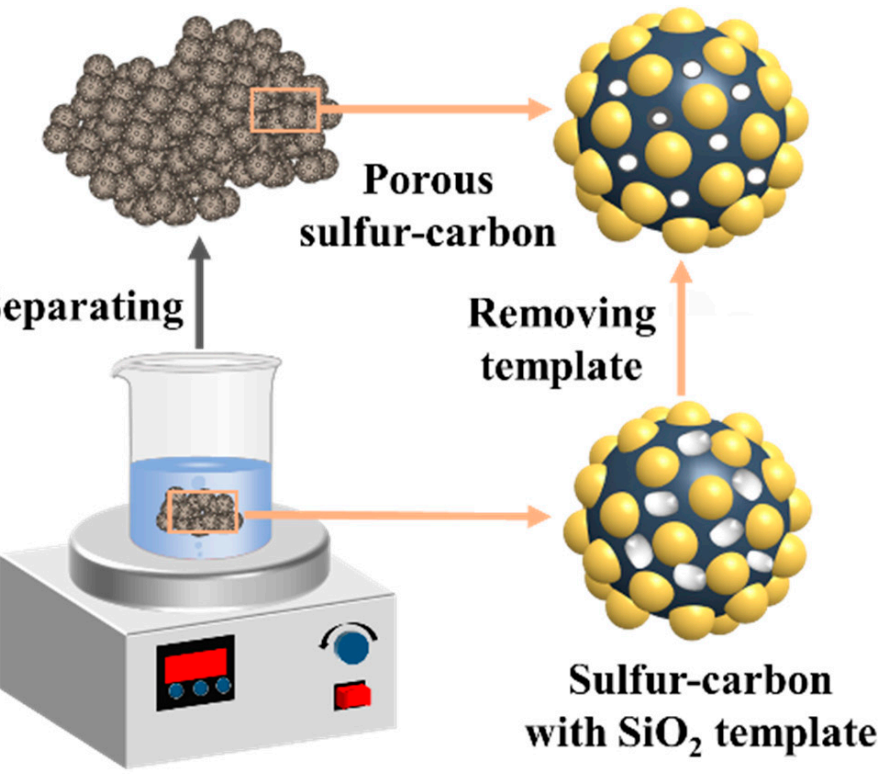

Figure 1. Schematic illustration of the synthesis process for S-C.

Figure 3 shows the morphologies of S-Cs with different HF etching times. These images display the high-solution local microscopies of individual particles, in which the 
sizes of individual particles are in the range of 100-200 mesh. As shown, the morphology of S-C was significant dependent on the HF etching time. The S-C without HF etching displayed a dense surface, and there were negligible pores observed on the S-C surface. After etching with $\mathrm{HF}$, abundant pores were generated on the S-C surface, and more pores were generated with the extension of the HF etching time from 5 to $10 \mathrm{~h}$. Thus, the $\mathrm{SiO}_{2}$ was embedded in the carbon structure as a template, which could be removed by using the HF solution to induce the formation of a porous structure. However, upon reaching a higher HF etching time, the resultant carbon framework collapsed, which might have affected the internal diffusion of mercury. Therefore, a $\mathrm{SiO}_{2}$ template was used to achieve the adjustable preparation of porous carbons.

Table 1. Pore structure parameters of various S-Cs with different HF etching times.

\begin{tabular}{ccccc}
\hline HF Etching Time (h) & $\begin{array}{c}\text { Total Surface Area } \\
\left(\mathbf{m}^{\mathbf{2}} \cdot \mathbf{g}^{-\mathbf{1}}\right)\end{array}$ & $\begin{array}{c}\text { Surface Area of } \\
\text { Micropores }\left(\mathbf{m}^{\mathbf{2}} \cdot \mathbf{g}^{-\mathbf{1}}\right)\end{array}$ & $\begin{array}{c}\text { Pore Volume } \\
\left(\mathbf{c m}^{\mathbf{3}} \cdot \mathbf{g}^{-\mathbf{1}} \mathbf{)}\right.\end{array}$ & $\begin{array}{c}\text { Pore Diameter } \\
(\mathbf{n m})\end{array}$ \\
\hline 0 & 180.92 & 143.33 & 0.29 & 6.32 \\
5 & 267.66 & 263.68 & 0.50 & 7.43 \\
10 & 318.50 & 335.88 & 0.58 & 7.31 \\
\hline
\end{tabular}

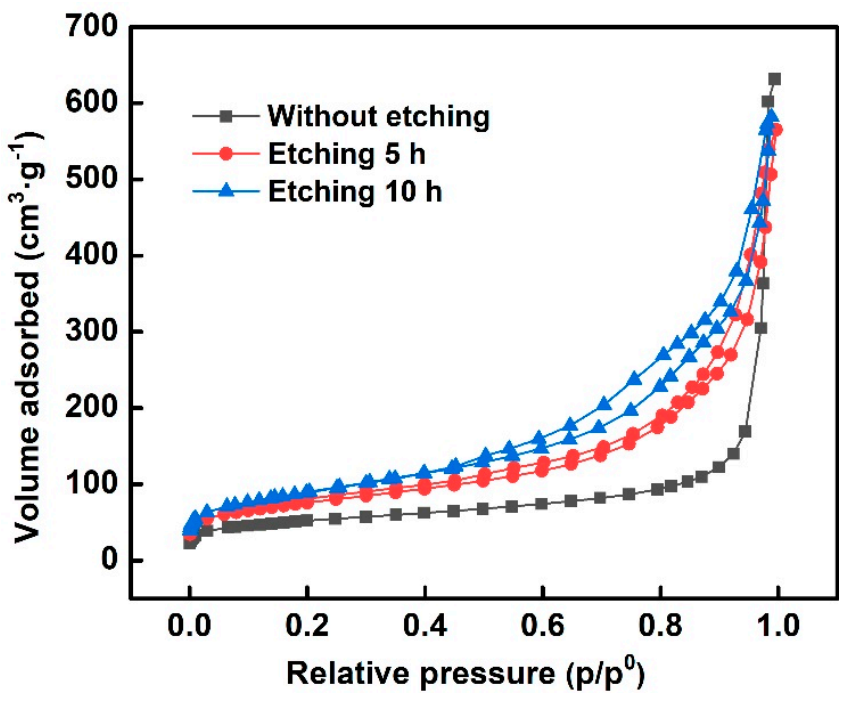

(a)

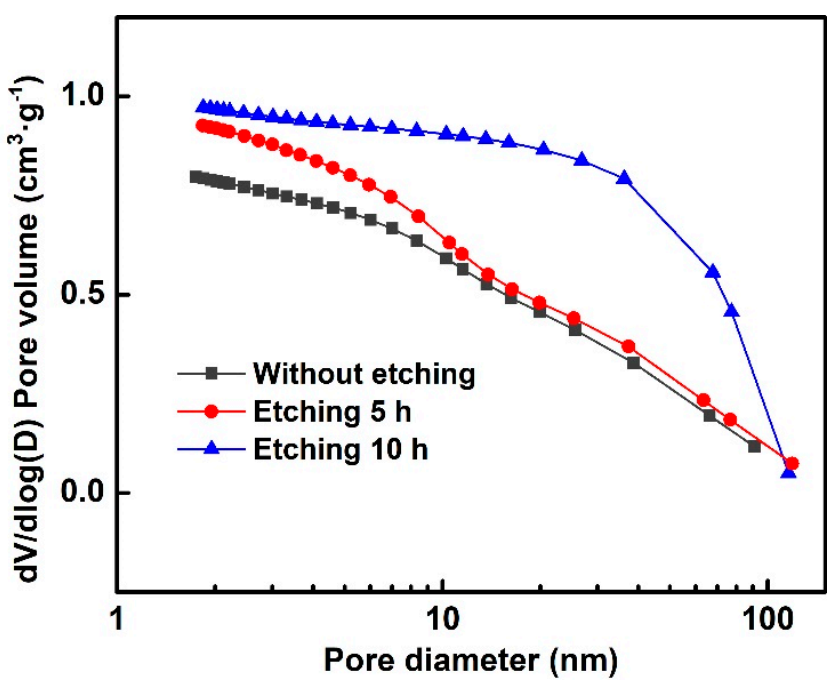

(b)

Figure 2. (a) $\mathrm{N}_{2}$ absorption-desorption isotherms and (b) pore size distributions of S-C.

The surface-functional groups of S-C were studied by using FTIR. As shown in Figure 4, there were four main peaks on the FTIR spectra, which could be assigned to the $\mathrm{C}-\mathrm{OH}$ (3392 and $\left.615 \mathrm{~cm}^{-1}\right)$ and aromatic $C=C\left(1626\right.$ and $\left.1100 \mathrm{~cm}^{-1}\right)$ [49]. Figure 5 shows the XPS spectra for S-C. As shown in Figure 5a, the spectra for high-solution C 1s spectra could be divided into three peaks at 284.8,286.0, and $288.8 \mathrm{eV}$, assigned to the characteristic peaks of $\mathrm{C}=\mathrm{C}, \mathrm{C}-\mathrm{O}$, and $\mathrm{C}=\mathrm{O}[30]$. Figure $5 \mathrm{~b}$ shows the $\mathrm{O} 1 \mathrm{~s}$ spectra for $\mathrm{C}-\mathrm{S}$, in which the peaks at $531.5,532.3$, and $533.3 \mathrm{eV}$ are regarded as $\mathrm{C}-\mathrm{OH}, \mathrm{C}-\mathrm{O}$, and $\mathrm{O}-\mathrm{H}$ [31]. Figure $5 \mathrm{c}$ shows the $\mathrm{S}$ spectra for S-C. The sulfur on the S-C existed in four forms. The two peaks at 164.2 and $165.3 \mathrm{eV}$ corresponded to $\mathrm{S} 2 \mathrm{p} 3 / 2$ and $S \mathrm{2p} 1 / 2$ for thiophenic sulfur (i.e., $-\mathrm{C}-\mathrm{S}_{\mathrm{x}}-\mathrm{C}-\mathrm{-}, \mathrm{x}=1-2$ ), the small peak at $169.1 \mathrm{eV}$ could be assigned to sulfoxide [50], the peak at $166.2 \mathrm{eV}$ could be assigned to C-S, while the peaks at 167.2 and $170.3 \mathrm{eV}$ could be assigned to sulfate [51,52]. 


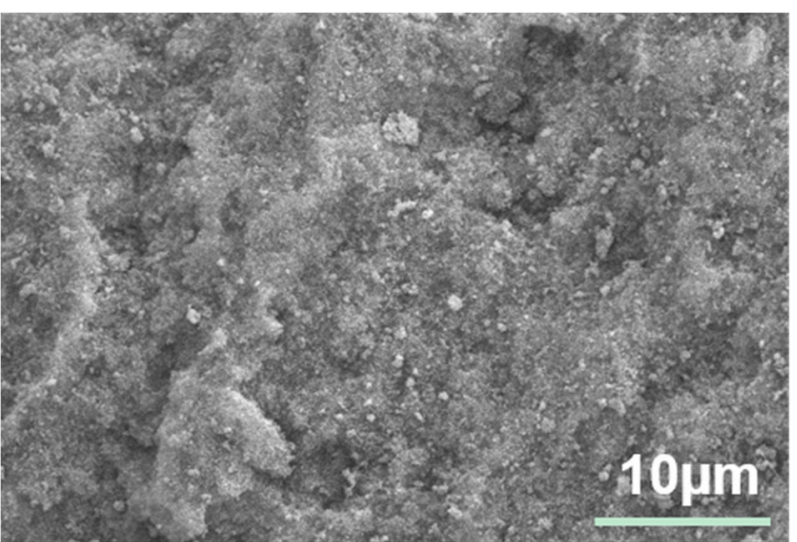

(a)

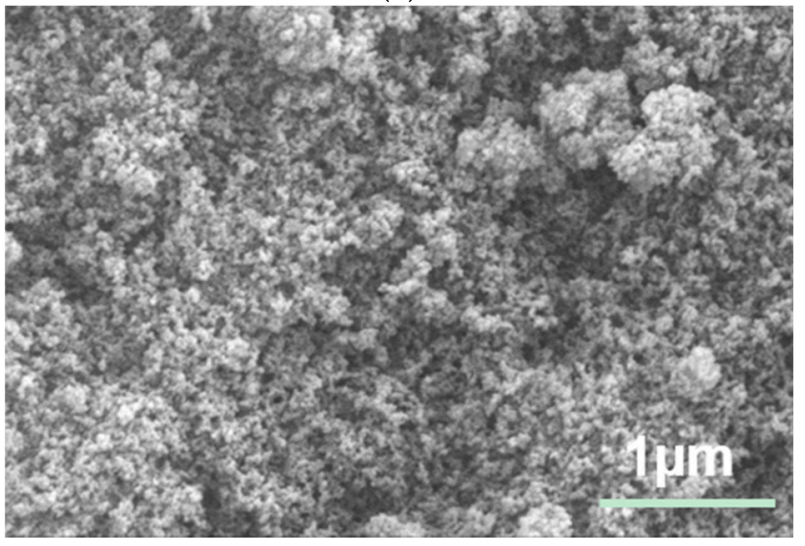

(c)

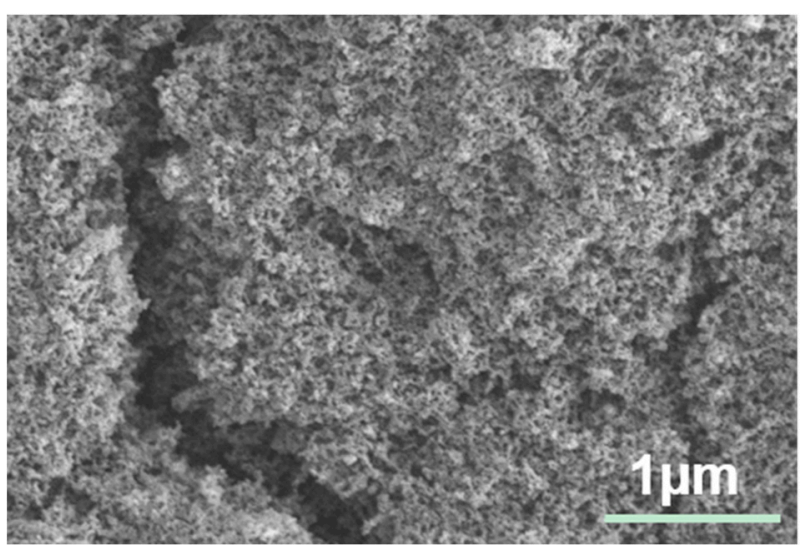

(b)

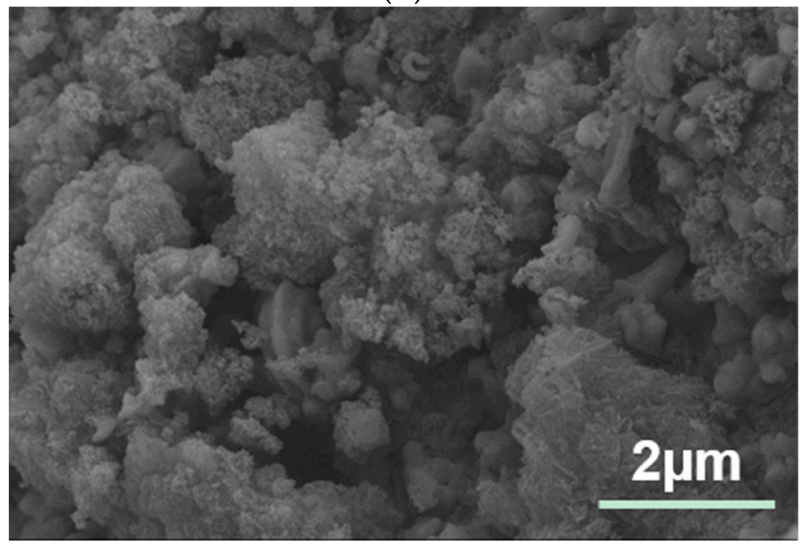

(d)

Figure 3. SEM images of S-C with HF etchings for (a) 0 h, (b) 5 h, (c) $10 \mathrm{~h}$, and (d) $20 \mathrm{~h}$.

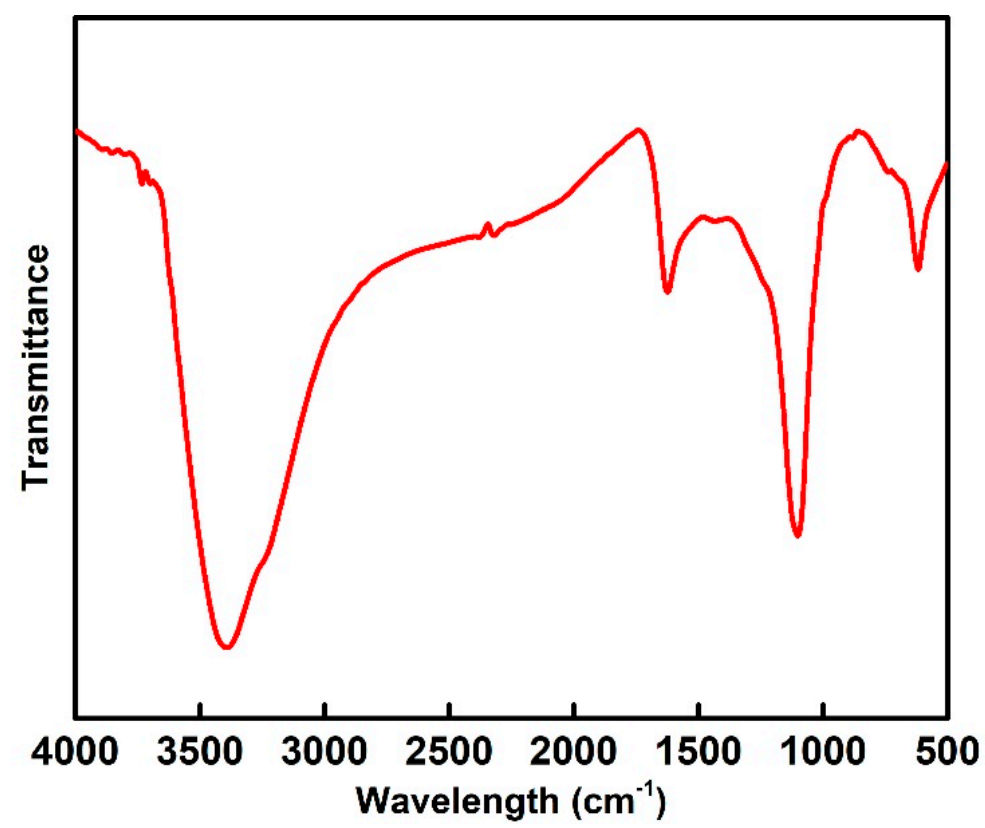

Figure 4. FTIR spectra of the synthetic S-C sample. 


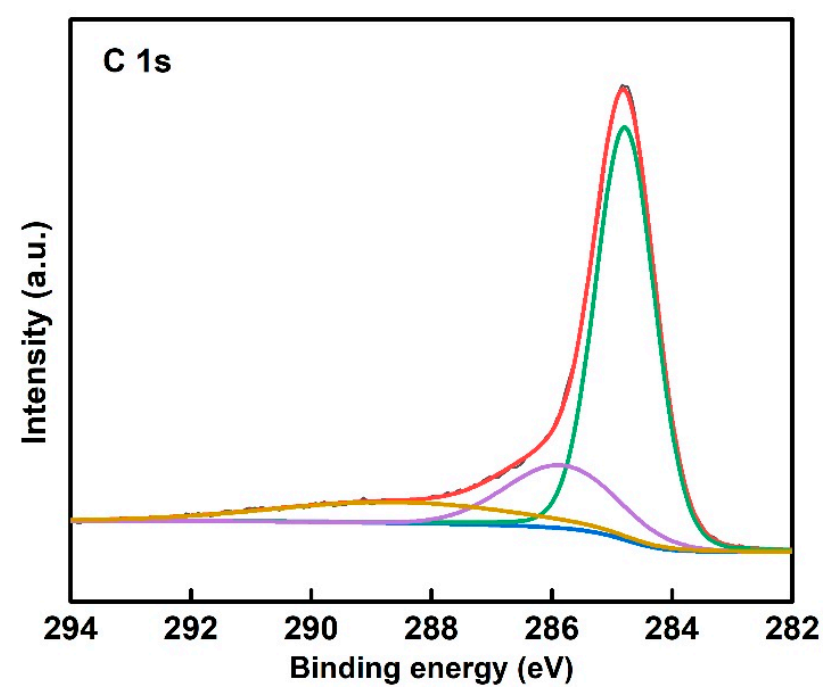

(a)

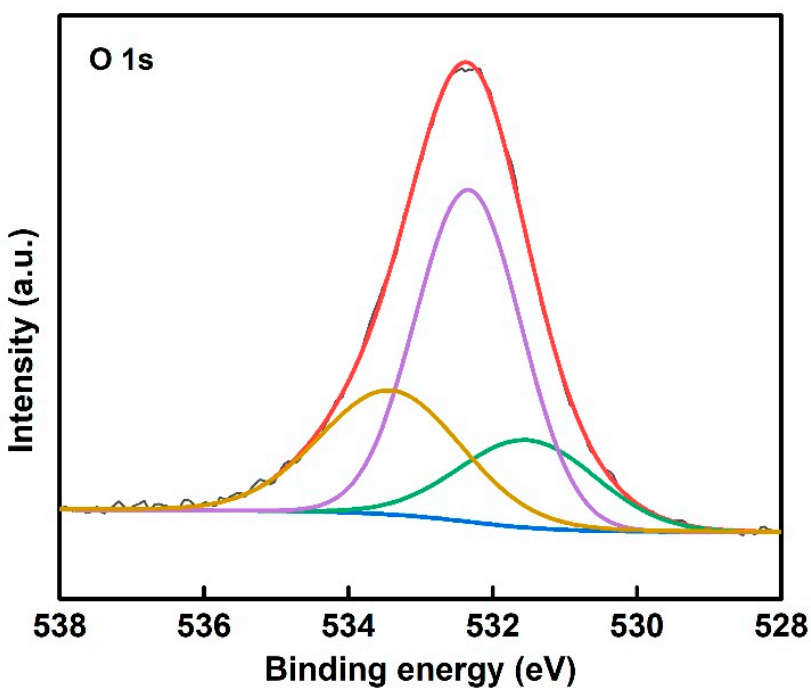

(b)

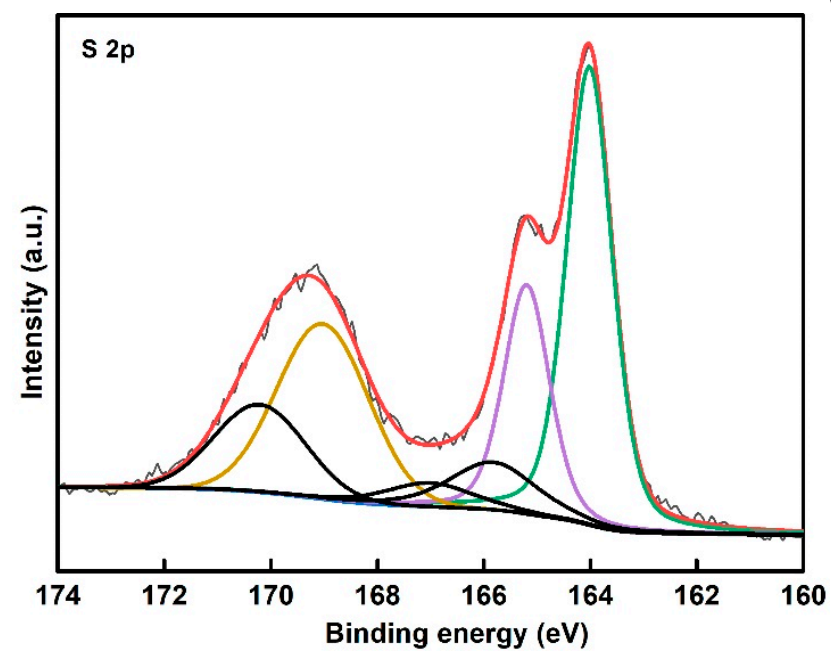

(c)

Figure 5. XPS spectra of S-C for (a) C 1s, (b) O 1s, and (c) S 2p.

\section{2. $\mathrm{Hg}^{0}$ Adsorption Capacity Tests}

Figure 6 shows the $\mathrm{Hg}^{0}$ adsorption performances of S-Cs with various HF etching times. As shown, the normalized-outlet $\mathrm{Hg}^{0}$ concentration of S-C without etching climbed dramatically to above 0.90 . Thus, the $\mathrm{S}-\mathrm{C}$ without etching has a poor $\mathrm{Hg}^{0}$ adsorption performance, and the removal rate of $\mathrm{Hg}^{0}$ is only below $10 \%$. However, after the $\mathrm{HF}$ etching, the $\mathrm{S}-\mathrm{C}$ displayed far superior $\mathrm{Hg}^{0}$ removal performances. The HF etching times played significant roles in the $\mathrm{Hg}^{0}$ adsorption of $\mathrm{S}-\mathrm{C}$. After etching for $5 \mathrm{~h}$, the concentration of $\mathrm{Hg}^{0}$ at the normalized outlet remained below 0.2 . With the extension of the etching time to $10 \mathrm{~h}$, the $\mathrm{Hg}^{0}$ adsorption performance of S-C can be further improved. However, a too-long etching time resulted in a decrease in $\mathrm{Hg}^{0}$ adsorption performance. This is attributed to the fact that $\mathrm{HF}$ etching can remove the $\mathrm{SiO}_{2}$ template to generate abundant pores on S-C, which allows for accessible mercury molecule transportation. As a result, the sulfur in S-C can be accessible sufficiently for binding mercury. However, the excessive etching will result in the collapse of the framework of carbons, hence the weakening of the $\mathrm{Hg}^{0}$ adsorption on $\mathrm{S}-\mathrm{C}$. 


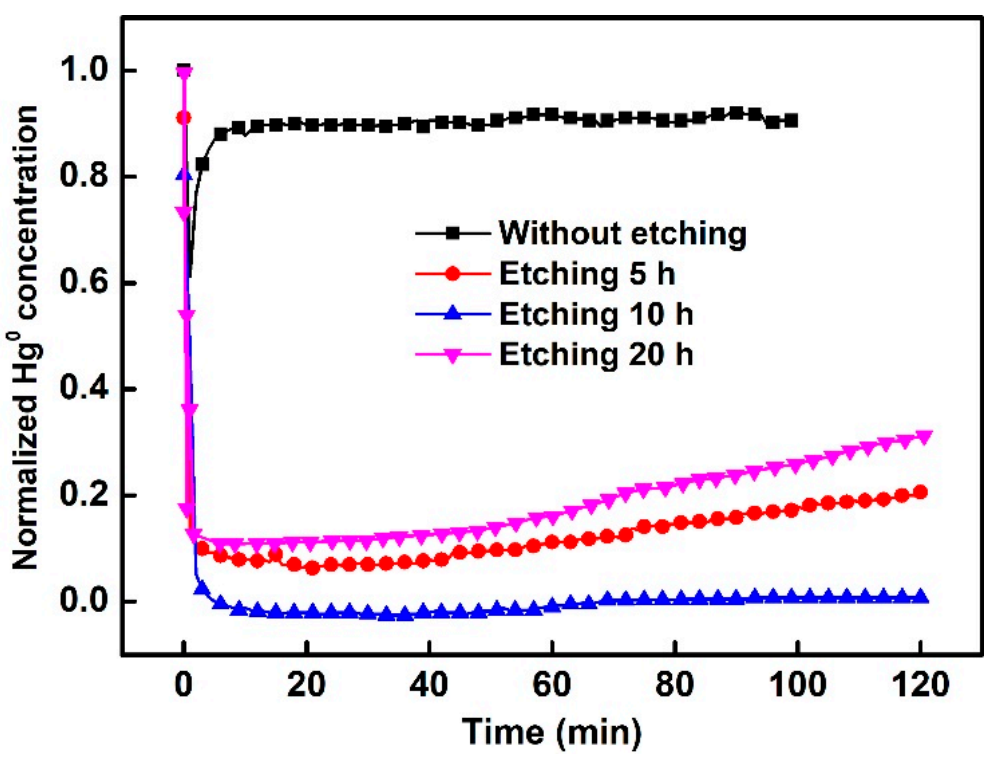

Figure 6. $\mathrm{Hg}^{0}$ removal performances of $\mathrm{S}-\mathrm{C}$ with different etching times.

The saturated adsorption capacity of an adsorbent is an important index to use to evaluate the adsorption performances of materials, so it is necessary to study the change in S-C adsorption capacity with time. The curve of $\mathrm{Hg}^{0}$ adsorption capacity changing over time is shown in Figure 7. When the reaction duration was $1200 \mathrm{~min}$, the adsorption capacity of $\mathrm{Hg}^{0}$ exceeded $50 \%$ and reached $45.39 \mathrm{mg} \cdot \mathrm{g}^{-1}$. In addition, it can be seen from the figure that the adsorption rate increases first and then decreases with time, and the slope is zero when the adsorption is saturated. Adsorption kinetic models can be adopted to investigate the process of $\mathrm{Hg}^{0}$ adsorption and the dominant controlling factors. The pseudo-first-order-based kinetic model is the most common adsorption kinetic model. $\operatorname{Ln}\left(q_{e}-q_{t}\right)$ is used to plot $t$, and the adsorption mechanism conforms to the pseudo-firstorder model if a straight line can be obtained. The pseudo-second-order model is based on the assumption that the adsorption rate is controlled by the chemisorption mechanism. Elovich describes a series of reaction mechanism processes, which are suitable for processes with large activation energy changes in reactions and for complex heterogeneous diffusion processes. The intra-particle diffusion model is commonly used to analyze the control steps in the reaction. Generally, the material adsorption process is divided into two processes: adsorbent surface adsorption and slow pore diffusion. If the fitting result fails to reach the origin, it indicates that the internal diffusion of the material is not the only step to controlling the adsorption process. As shown in Figure 8, the pseudo-first-order model was closest to the adsorption process of $\mathrm{Hg}^{0}$ on $\mathrm{S}-\mathrm{C}$, with an extremely high correlation coefficient $\left(R^{2}=0.9982\right)$. The saturation adsorption capacity of S-C was simulated as $89.90 \mathrm{mg} \cdot \mathrm{g}^{-1}$. When the molar ratio of $\mathrm{Hg}: \mathrm{S}$ is $1: 1$, it is equivalent to $55 \%$ of the sulfur accessibility in $\mathrm{Hg}^{0}$ adsorption. For comparison, the $\mathrm{Hg}^{0}$ saturation adsorption capacity of a sulfur-loaded commercial activated carbon (S/C) was also investigated. It should be noted that the S/C possessed a higher sulfur content and surface area compared with S-C. However, the saturation adsorption capacity of $S / C$ was less than $1 \mathrm{mg} \cdot \mathrm{g}^{-1}$, which was much lower compared with its theoretical adsorption capacity of $352.1 \mathrm{mg} \cdot \mathrm{g}^{-1}$. Thus, most of the sulfur in S/C was not adopted sufficiently for binding mercury, although it possessed a higher surface area. It fully shows that the key to $\mathrm{Hg}^{0}$ adsorption improvements lies in the high dispersion of active sulfur species [53]. Thus, the molten-salt pyrolysis synthesis strategy toward sulfur-functionalized carbon would be more superior compared with other traditional methods, such as impregnation when significantly dispersing the active components (i.e., sulfur). 


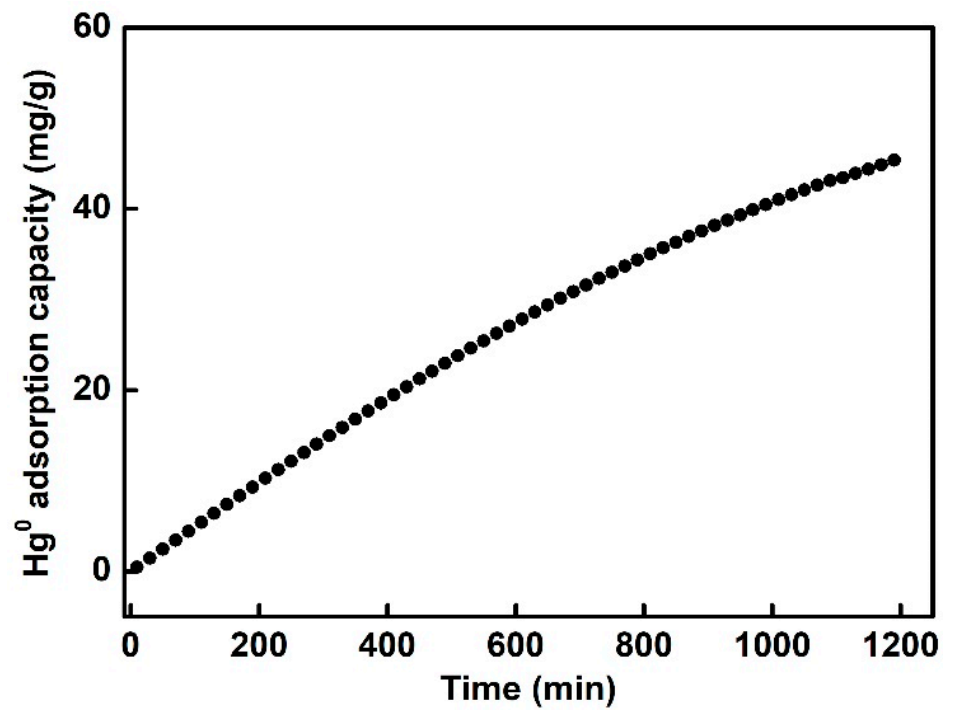

Figure $7 . \mathrm{Hg}^{0}$ adsorption-capacity curve for $\mathrm{S}-\mathrm{AC}$ as a function of time.

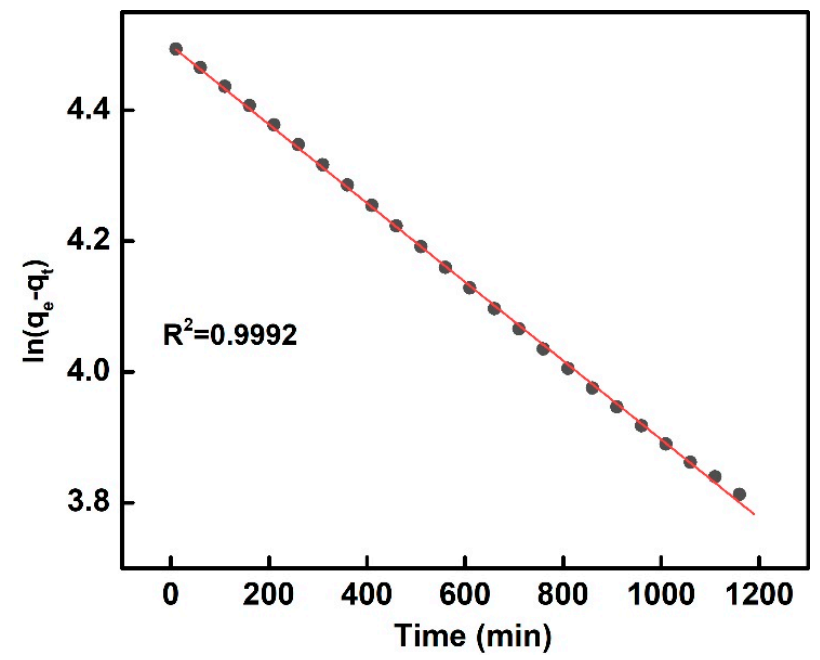

(a)

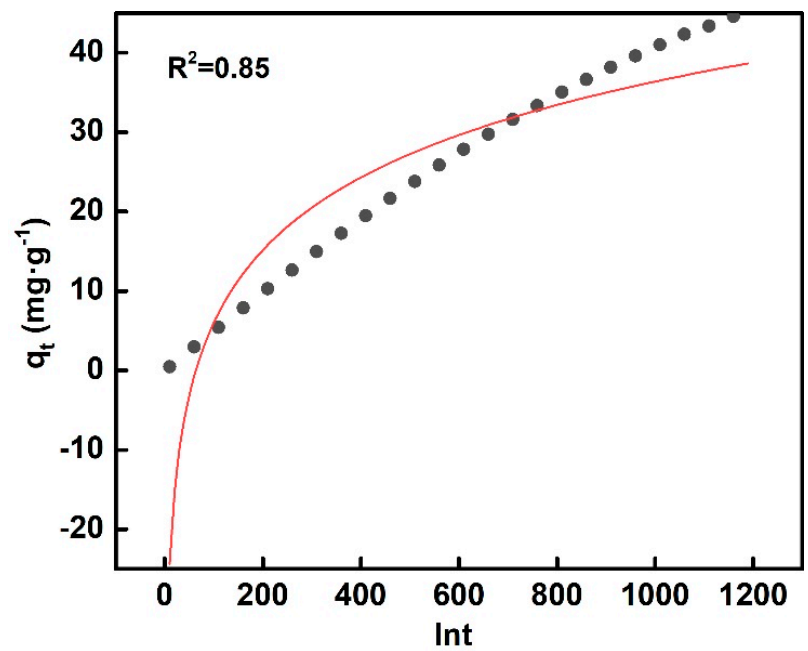

(c)

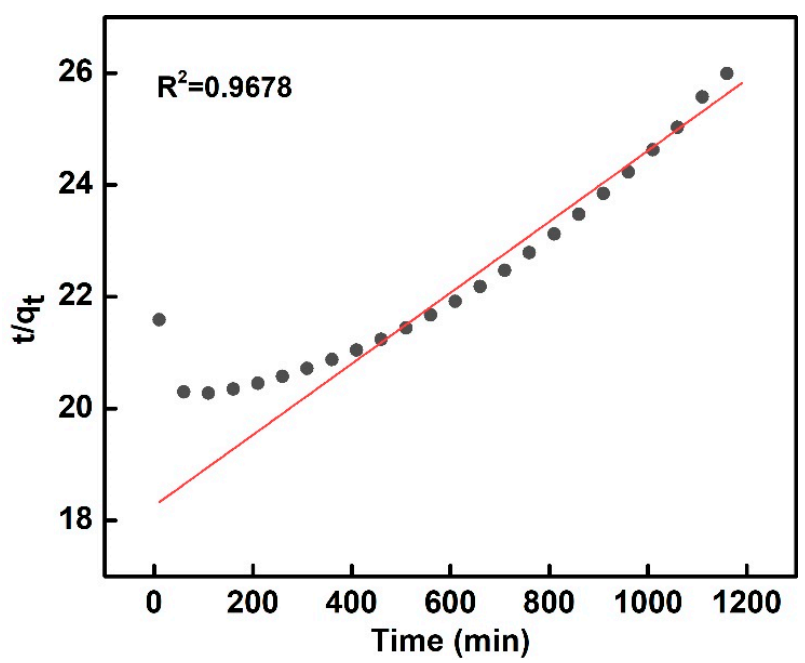

(b)

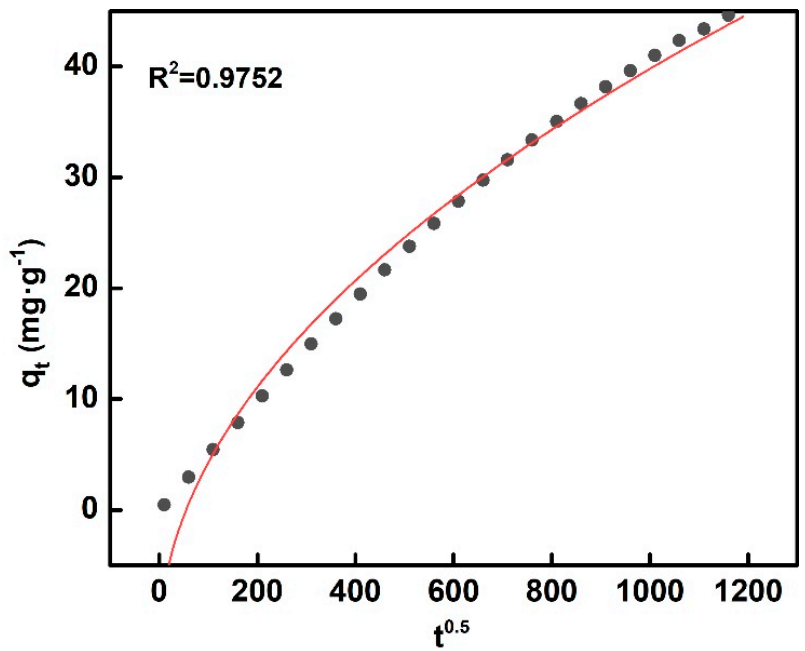

(d)

Figure 8. $\mathrm{Hg}^{0}$ adsorption behaviors of S-C simulated by the (a) pseudo-first-order, (b) pseudo-secondorder, (c) Elovich, and (d) intra-particle diffusion models. 


\subsection{Impact of Operation Conditions on $\mathrm{Hg}^{0}$ Adsorption Capacity}

An excellent adsorbent should have a good stability at various conditions. Figure 9 shows the influence of temperature on the $\mathrm{Hg}^{0}$ adsorption capacities of S-C and S/C. The normalized-outlet $\mathrm{Hg}^{0}$ concentration when passing through the $\mathrm{S}-\mathrm{C}$ was maintained below $0.05 \mathrm{in}$ a wide reaction temperature range of $25-125^{\circ} \mathrm{C}$. This suggests that an above $95 \% \mathrm{Hg}^{0}$ adsorption efficiency was obtained; even the sorbent dosage was as low as $5 \mathrm{mg}$. This wide temperature range proves that the $\mathrm{S}-\mathrm{C}$ can be applied flexibly at different scenes for $\mathrm{Hg}^{0}$ removal. In contrast, the $\mathrm{S} / \mathrm{C}$ exhibited significantly different $\mathrm{Hg}^{0}$ adsorption capacities under various temperatures, in which relatively limited $\mathrm{Hg}^{0}$ adsorption capacities were obtained at low temperatures. Even at the optimum reaction temperature and the same amount of adsorbent, the concentration of $\mathrm{Hg}^{0}$ at the normalized outlet is still higher than 0.15 , much higher than S-C. Depending on the preferred temperature range, setting the $\mathrm{S} / \mathrm{C}$ upstream of the ESP is the ideal application in which the $\mathrm{Hg}^{0}$ adsorption capacity of $\mathrm{S}-\mathrm{C}$ might be affected by various flue gas components, such as high concentrations of fly ash, $\mathrm{SO}_{2}$, and $\mathrm{NO}_{2}$.

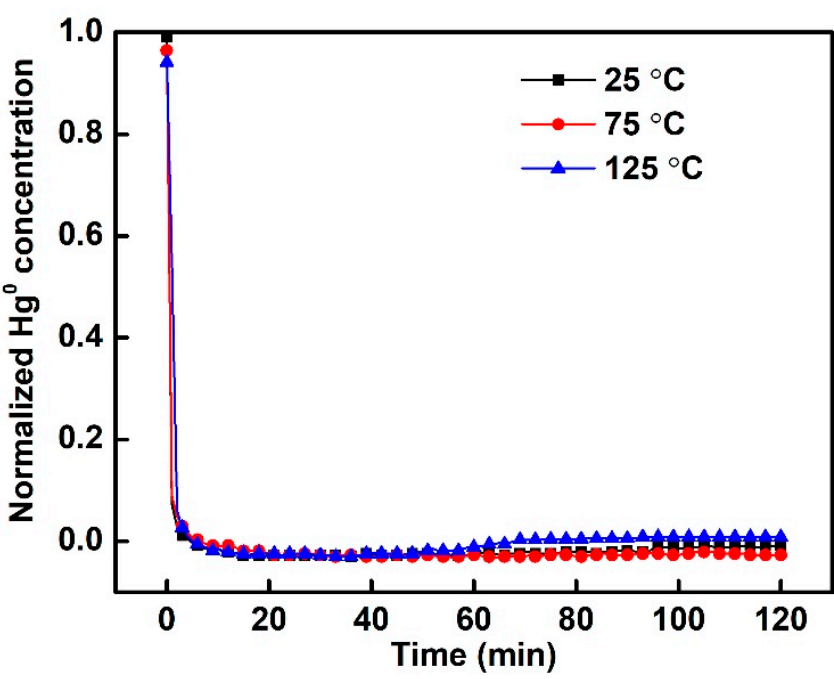

(a)

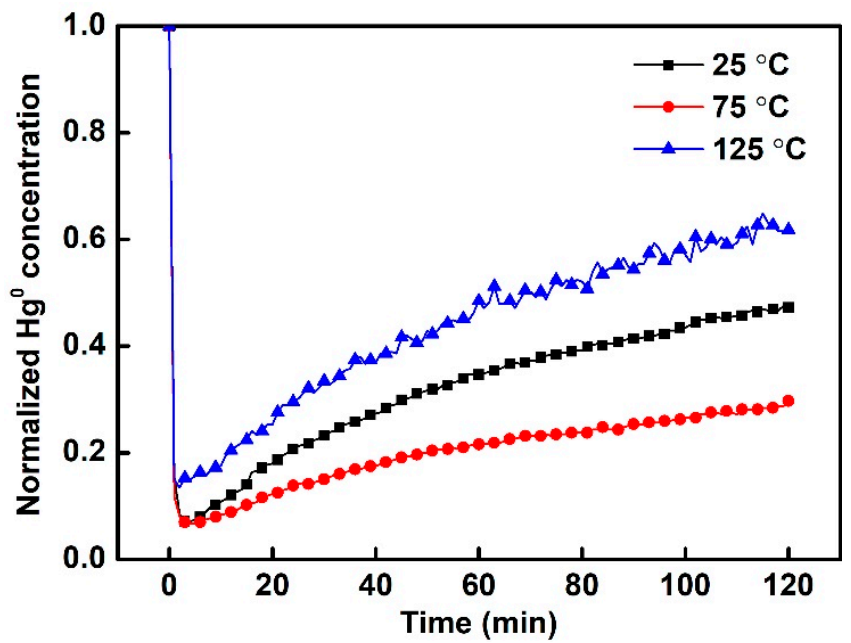

(b)

Figure 9. $\mathrm{Hg}^{0}$ removal performances of (a) S-C and (b) S/C under different temperatures.

According to previous studies, $\mathrm{SO}_{2}$ and $\mathrm{H}_{2} \mathrm{O}$ generally compete with $\mathrm{Hg}^{0}$ for adsorption sites, hence exhibiting inhibitive effects on the $\mathrm{Hg}^{0}$ removal over carbonaceous sorbents $[54,55]$. However, the S-C exhibited an excellent resistance to these detrimental flue gas components. Figure 10a-c show that, in the presence of $\mathrm{SO}_{2}, \mathrm{H}_{2} \mathrm{O}$, as well as $\mathrm{NO}$, the $\mathrm{Hg}^{0}$ removal performance was very similar to that under a pure $\mathrm{N}_{2}$ atmosphere. Even adding $1200 \mathrm{ppm}$ of $\mathrm{SO}_{2}, 12 \% \mathrm{H}_{2} \mathrm{O}$, or $400 \mathrm{ppm}$ of $\mathrm{NO}$, the normalized-outlet $\mathrm{Hg}^{0}$ concentration was kept at less than 0.05 . As a direct comparison, the adsorption performance of $\mathrm{S} / \mathrm{C}$ for $\mathrm{Hg}^{0}$ was investigated. As shown in Figure $10 \mathrm{~d}$, the $\mathrm{SO}_{2}, \mathrm{H}_{2} \mathrm{O}$, and $\mathrm{NO}$ significantly weakened the adsorption capacity of S/C. These results could fully demonstrate the excellent resistance of S-C to the detrimental impacts of flue gas impurities compared with commercial activated carbon, which would facilitate the real-world applications. 


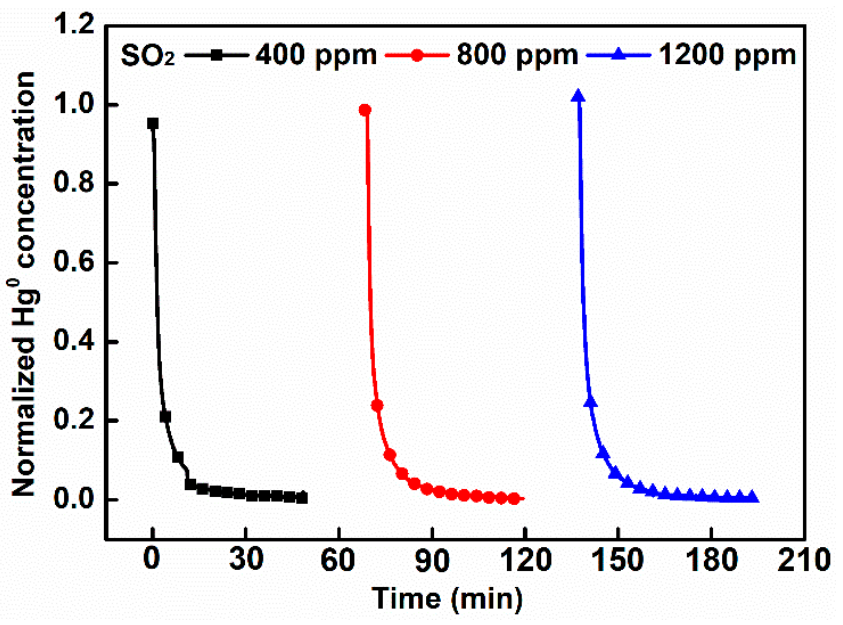

(a)

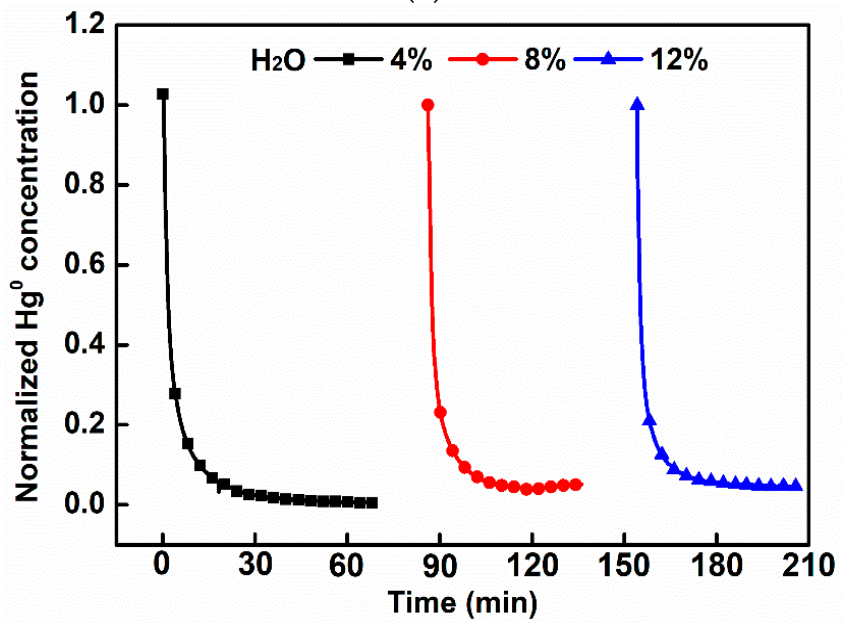

(c)

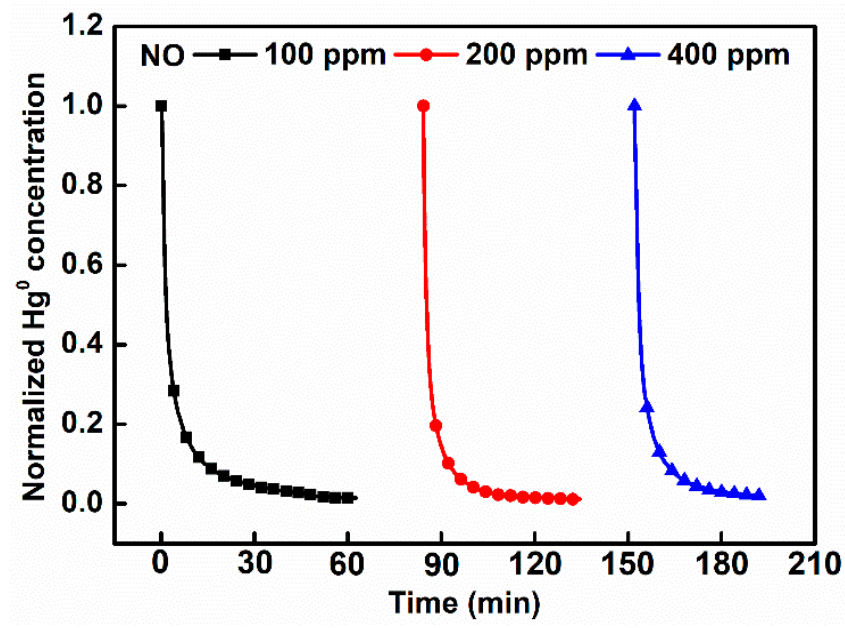

(b)

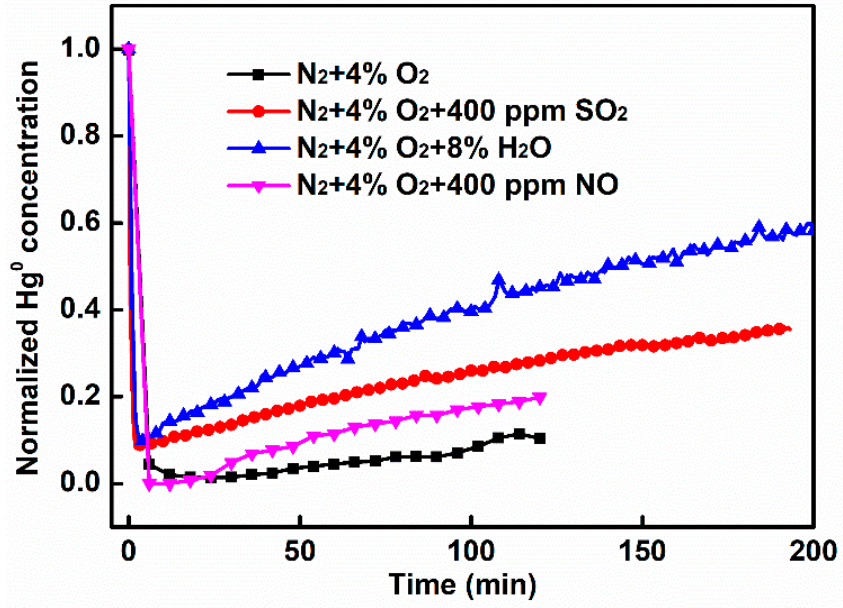

(d)

Figure 10. Effects of (a) $\mathrm{SO}_{2}$, (b) $\mathrm{NO}$, and (c) $\mathrm{H}_{2} \mathrm{O}$ on the $\mathrm{Hg}^{0}$ removal performances of S-Cs and (d) effects of flue gas components on the $\mathrm{Hg}^{0}$ removal performances of $\mathrm{S} / \mathrm{Cs}$.

\subsection{Reaction Mechanism}

To study the mechanism of a $\mathrm{Hg}^{0}$ removal on $\mathrm{S}-\mathrm{C}$, the valence states of elements on spent S-C after adsorbing mercury were investigated by using XPS. Figure 11a shows that there is no significant change in the spectral binding energy of $C 1$ s for the spent adsorbent, indicating that $\mathrm{C}$ did not participate in the $\mathrm{Hg}^{0}$ adsorption [56]. Figure $11 \mathrm{~b}$ shows the $\mathrm{O}$ 1s spectra for the spent adsorbent. The spectra of $\mathrm{O} 1 \mathrm{~s}$ can be divided into four separate corresponding peaks: $\mathrm{C}=\mathrm{O}, \mathrm{C}-\mathrm{O}-\mathrm{C}, \mathrm{COOH}$, and $\mathrm{H}_{2} \mathrm{O}$ at 531.3, 532.5, 533.8, and $536.1 \mathrm{eV}$, respectively [57]. After the $\mathrm{Hg}^{0}$ adsorption, part of the $\mathrm{C}-\mathrm{O}$ groups changed to $\mathrm{C}=\mathrm{O}$, and $\mathrm{H}_{2} \mathrm{O}$ was generated on the adsorbent surface, which may have been caused by a charge imbalance after binding $\mathrm{Hg}^{0}$. Figure 11c shows the $\mathrm{S} 2 \mathrm{p}$ for the spent adsorbent, including only two peaks: C-S at $163.94 \mathrm{eV}$ and thiophene at $165.22 \mathrm{eV}$ [58]. The transformations of sulfur species on the spent adsorbent indicate that sulfur played a crucial role in the $\mathrm{Hg}^{0}$ removal. The absolute content of thiophene and C-S decreased after adsorbing $\mathrm{Hg}^{0}$, especially the peaks for sulfoxide, which disappeared compared with the fresh adsorbent. This variation indicates that thiophene (i.e., $\left.-C-S_{x}-C-, x=1-2\right)$, sulfoxide, and C-S were beneficial to improving the $\mathrm{Hg}^{0}$ removal capacity. This is in line with a previous study [59], i.e., findings that the sulfur in sulfide existing in a low state as well as the reducing sulfur (such as thiosulfone) had a high affinity with the $\mathrm{Hg}^{0}$ atom. Electrons around the sulfur atom were easy to combine with $\mathrm{Hg}^{0}$, which was conducive to the removal of mercury. Figure $11 \mathrm{~d}$ shows that the two peaks of $\mathrm{Hg} 4 \mathrm{f}$ corresponded to the peaks of 103 and 107 
$\mathrm{eV}$ of $\mathrm{HgS}$ [60], further demonstrating that the sulfur in the adsorbent was active for binding $\mathrm{Hg}^{0}$.

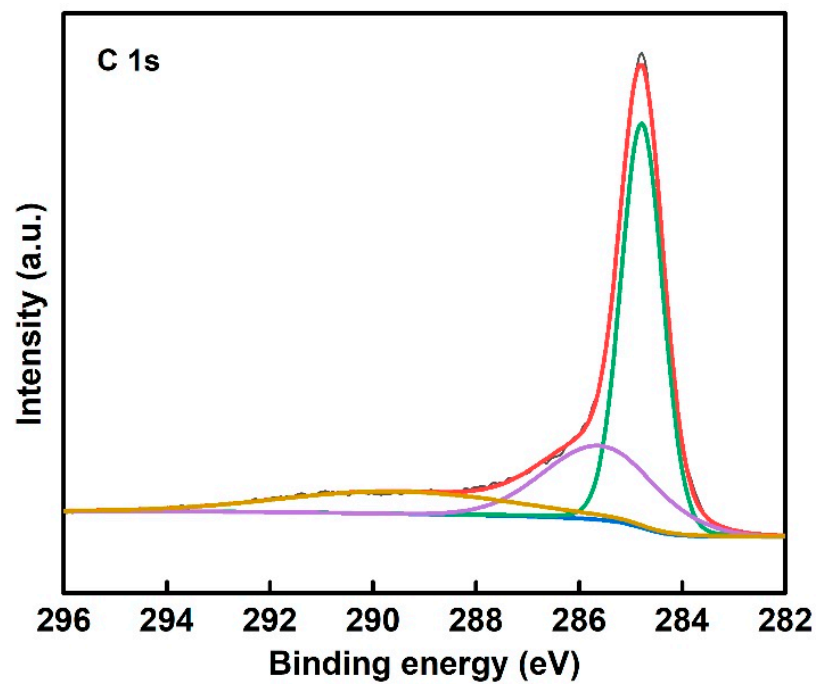

(a)

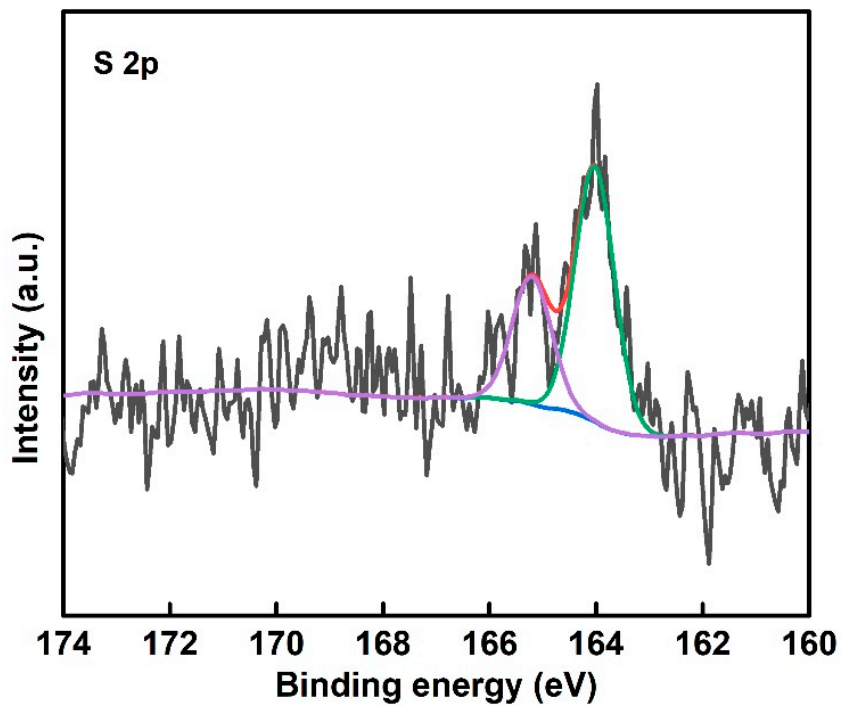

(c)

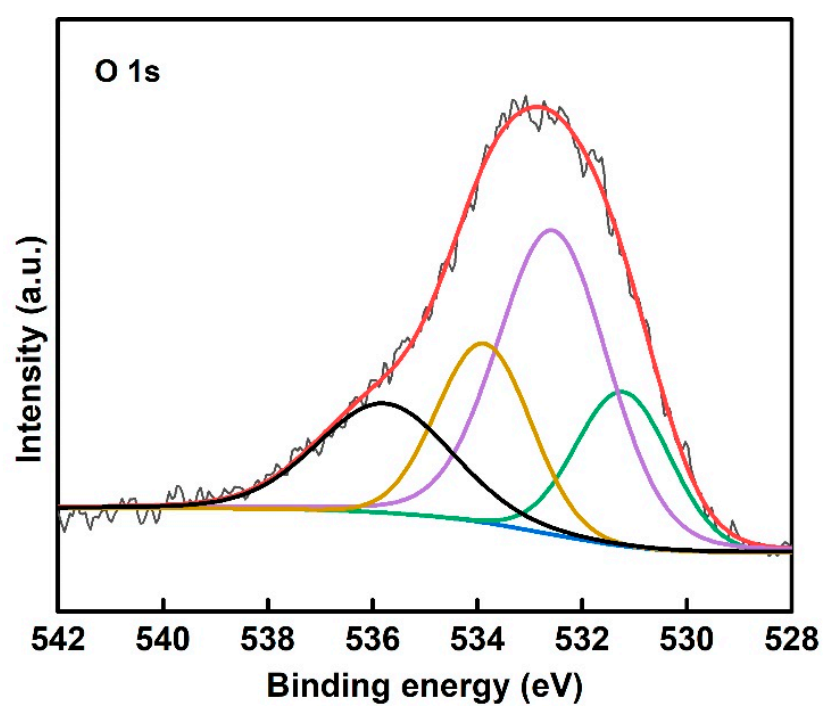

(b)

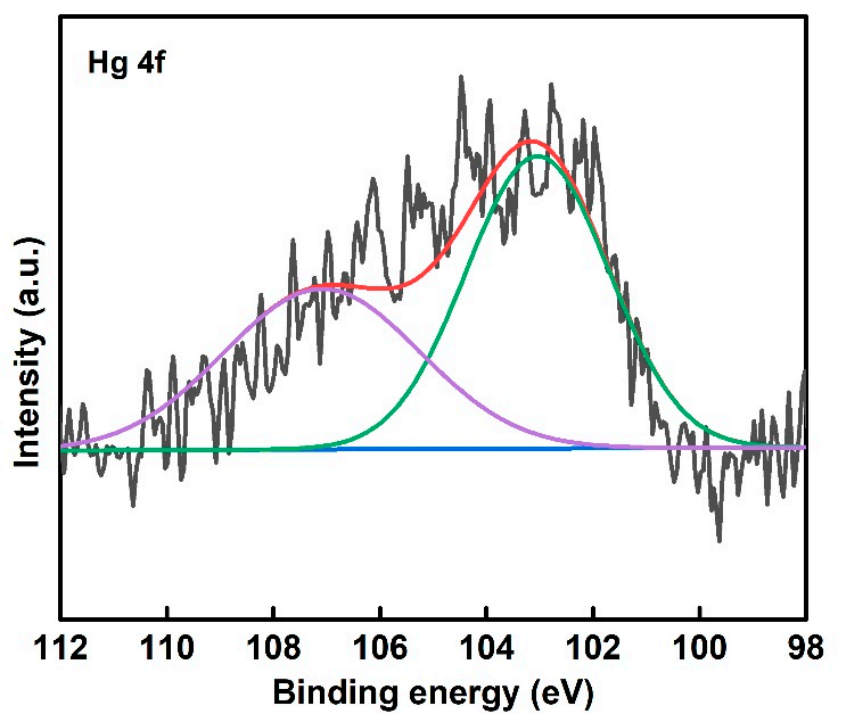

(d)

Figure 11. (a) C 1s, (b) O 1s, (c) S 2p, and (d) Hg 4f spectra of spent S-C.

\section{Conclusions}

Sulfur-functionalized carbon (S-C) derived from a molten-salt pyrolysis strategy was employed for a $\mathrm{Hg}^{0}$ removal. Abundant pores could be generated by using a $\mathrm{SiO}_{2}$ hard template and a subsequent HF etching step. The HF etching time significantly affected the $\mathrm{Hg}^{0}$ removal performances of S-Cs. With an HF etching time of $10 \mathrm{~h}$, the S-C presented the best $\mathrm{Hg}^{0}$ removal performance, the saturation $\mathrm{Hg}^{0}$-adoption capacity of which reached $89.90 \mathrm{mg} \cdot \mathrm{g}^{-1}$. This value far exceeded that of the commercial sulfur-loaded activated carbon (S/C), which was specialized for $\mathrm{Hg}^{0}$ removals. The S-C displayed a good applicability at $25-125^{\circ} \mathrm{C}$, while the $\mathrm{S} / \mathrm{C}$ could be adopted around only $125^{\circ} \mathrm{C}$ since the $\mathrm{Hg}^{0}$ adsorption performances decreased when deviating from this temperature. The $\mathrm{SO}_{2}, \mathrm{NO}$, and $\mathrm{H}_{2} \mathrm{O}$ had negligible adverse effects on $\mathrm{Hg}^{0}$ adsorption over $\mathrm{S}-\mathrm{C}$. The good $\mathrm{Hg}^{0}$ removal performance of S-C was ascribed to the existence of reduced sulfurs, such as thiophene, sulfoxide, and C-S, which have high affinities toward $\mathrm{Hg}^{0}$, and the fact that gaseous $\mathrm{Hg}^{0}$ was converted into $\mathrm{HgS}$ after the adsorption. These results indicate that molten-salt pyrolysis 
can simultaneously achieve the carbonization and functionalization of sulfur-containing organic precursors and is an ideal method for preparing carbonaceous adsorbents for $\mathrm{Hg}^{0}$ removal.

Author Contributions: Conceptualization, J.Y.; Writing-original draft, J.Y.; Formal analysis, J.Y.; Investigation, H.X.; Writing-review \& editing, H.X.; Software, F.M. and W.Q.; Methodology, F.M.; Supervision, Q.G.; Validation, Q.G., T.H. and Z.Y.; Data curation, T.H. and W.Q.; Visualization, Z.Y.; Resources, H.L.; Project administration, H.L. All authors have read and agreed to the published version of the manuscript.

Funding: This research received no external funding.

Institutional Review Board Statement: Not applicable.

Informed Consent Statement: Not applicable.

Data Availability Statement: No data was reported.

Acknowledgments: This project was supported by the National Natural Science Foundation of China (51906260), the Natural Science Foundation of Hunan Province, China (2021JJ30851), the Postgraduate Scientific Research Innovation Project of Hunan Province (CX20210098), the Foundation of State Key Laboratory of High-efficiency Utilization of Coal and Green Chemical Engineering (Grant No. 2022-K09 and 2022-K52), and the Key Research and Development Program of Sichuan Province (2021YFG0117).

Conflicts of Interest: The authors declare no conflict of interest.

\section{References}

1. Landrigan, P.J.; Wright, R.O.; Birnbaum, L.S. Mercury toxicity in children. Science 2013, 342, 1447. [CrossRef] [PubMed]

2. Richardson, J.B.; Moore, L. A tale of three cities: Mercury in urban deciduous foliage and soils across land-uses in Poughkeepsie NY, Hartford CT, and Springfield MA USA. Sci. Total Environ. 2020, 715, 136869. [CrossRef] [PubMed]

3. Li, M.; Yang, H.E.; Lu, H.; Wu, T.; Zhou, D.; Liu, Y. Investigation into the Classification of Tight Sandstone Reservoirs via Imbibition Characteristics. Energies 2018, 11, 2619. [CrossRef]

4. Masoomi, I.; Kamata, H.; Yukimura, A.; Ohtsubo, K.; Schmid, M.O.; Scheffknecht, G. Investigation on the behavior of mercury across the flue gas treatment of coal combustion power plants using a lab-scale firing system. Fuel Process. Technol. 2020, 201, 106340. [CrossRef]

5. Lee, S.S.; Wilcox, J. Behavior of mercury emitted from the combustion of coal and dried sewage sludge: The effect of unburned carbon, Cl, Cu and Fe. Fuel 2017, 203, 749-756. [CrossRef]

6. Yang, S.; Liu, C.; Wang, P.; Yi, H.; Shen, F.; Liu, H. Cog $\mathrm{S}_{8}$ nanoparticles-embedded porous carbon: A highly efficient sorbent for mercury capture from nonferrous smelting flue gas. J. Hazard. Mater. 2021, 412, 124970. [CrossRef]

7. Fernández-Miranda, N.; Rodríguez, E.; Lopez-Anton, M.; García, R.; Martínez-Tarazona, M. A New Approach for Retaining Mercury in Energy Generation Processes: Regenerable Carbonaceous Sorbents. Energies 2017, 10, 1311. [CrossRef]

8. Mei, J.; Liao, Y.; Qin, R.; Sun, P.; Wang, C.; Ma, Y.; Qu, Z.; Yan, N.; Yang, S. Acceleration of $\mathrm{Hg}^{0}$ adsorption onto natural sphalerite by $\mathrm{Cu}^{2+}$ activation during flotation: Mechanism and applications in $\mathrm{Hg}^{0}$ recovery. Environ. Sci. Technol. 2020, 54, 7687-7696. [CrossRef]

9. Yu, M.Y.; Luo, G.Q.; Sun, R.Z.; Zou, R.J.; Li, X.; Yao, H. A mechanism study on effects of bromide ion on mercury re-emission in WFGD slurry. Chem. Eng. J. 2021, 406, 127010. [CrossRef]

10. Zhang, Y.; Yang, J.; Yu, X.; Sun, P.; Zhao, Y.; Zhang, J.; Chen, G.; Yao, H.; Zheng, C. Migration and emission characteristics of Hg in coal-fired power plant of China with ultra low emission air pollution control devices. Fuel Process. Technol. 2017, 158, 272-280. [CrossRef]

11. Wen, M.; Wu, Q.; Li, G.; Wang, S.; Li, Z.; Tang, Y.; Xu, L.; Liu, T. Impact of ultra-low emission technology retrofit on the mercury emissions and cross-media transfer in coal-fired power plants. J. Hazard. Mater. 2020, 396, 122729. [CrossRef] [PubMed]

12. Zhang, X.; Cui, L.; Li, Y.; Zhao, Y.; Dong, Y.; Cao, S. Adsorption and oxidation of mercury by montmorillonite powder modified with different copper compounds. Energy Fuels 2019, 33, 7852-7860. [CrossRef]

13. Heidel, B.; Klein, B. Reemission of elemental mercury and mercury halides in wet flue gas desulfurization. Int. J. Coal. Geol. 2017, 170, 28-34. [CrossRef]

14. Jia, T.; Ji, Z.; Wu, J.; Zhao, X.; Wang, F.; Xiao, Y.; Qi, X.; He, P.; Li, F. Nanosized $\mathrm{ZnIn}_{2} \mathrm{~S}_{4}$ supported on facet-engineered CeO nanorods for efficient gaseous elemental mercury immobilization. J. Hazard. Mater. 2021, 419, 126436. [CrossRef] [PubMed]

15. Xu, H.; Qu, Z.; Zong, C.; Quan, F.; Mei, J.; Yan, N. Catalytic oxidation and adsorption of $\mathrm{Hg}^{0}$ over low-temperature $\mathrm{NH}_{3}-\mathrm{SCR}$ $\mathrm{LaMnO}_{3}$ perovskite oxide from flue gas. Appl. Catal. B 2016, 186, 30-40. [CrossRef] 
16. Choi, S.; Lee, S.S. Mercury adsorption characteristics of Cl-impregnated activated carbons in simulated flue gases. Fuel 2021, 299, 120822. [CrossRef]

17. Dastgheib, S.A.; Mock, J.; Ilangovan, T. Evaluation of modified activated carbons for mercury reemission control during neutralization of a simulated wastewater from the direct contact cooler of a pressurized oxy-combustion process. Ind. Eng. Chem. Res. 2021, 60, 947-954. [CrossRef]

18. Huang, T.F.; Duan, Y.F.; Luo, Z.K.; Zhao, S.L.; Geng, X.Z.; Xu, Y.F.; Huang, Y.J.; Wei, H.Q.; Ren, S.J.; Wang, H.; et al. Influence of flue gas conditions on mercury removal by activated carbon injection in a pilot-scale circulating fluidized bed combustion system Ind. Eng. Chem. Res. 2019, 58, 15553-15561. [CrossRef]

19. Zhao, W.M.; Geng, X.Z.; Lu, J.C.; Duan, Y.F.; Liu, S.; Hu, P.; Xu, Y.F.; Huang, Y.J.; Tao, J.; Gu, X.B. Mercury removal performance of brominated biomass activated carbon injection in simulated and coal-fired flue gas. Fuel 2021, 285, 119131. [CrossRef]

20. Liu, D.J.; Li, B.; Liu, Y.X.; Wu, J. Copper sulfide-loaded boron nitride nanosheets for elemental mercury removal from simulated flue gas. Energy Fuel 2021, 35, 2234-2242. [CrossRef]

21. Park, J.; Lee, S.S. Adsorption of mercury by activated carbon prepared from dried sewage sludge in simulated flue gas. J. Air Waste Manag. Assoc. 2018, 68, 1077-1084. [CrossRef] [PubMed]

22. Yang, Z.; Li, H.; Liao, C.; Zhao, J.; Feng, S.; Li, P.; Liu, X.; Yang, J.; Shih, K. Magnetic rattle-type Fe $\mathrm{O}_{4} @ \mathrm{CuS}$ nanoparticles as recyclable sorbents for mercury capture from coal combustion flue gas. ACS Appl. Nano Mater. 2018, 1, 4726-4736. [CrossRef]

23. Oliveira, L.C.A.; Rios, R.V.R.A.; Fabris, J.D.; Garg, V.; Sapag, K.; Lago, R.M. Activated carbon/iron oxide magnetic composites for the adsorption of contaminants in water. Carbon 2002, 40, 2177-2183. [CrossRef]

24. Padak, B.; Wilcox, J. Understanding mercury binding on activated carbon. Carbon 2009, 47, 2855-2864. [CrossRef]

25. Li, H.; Zhu, L.; Wang, J.; Li, L.; Shih, K. Development of nano-sulfide sorbent for efficient removal of elemental mercury from coal combustion fuel gas. Environ. Sci. Technol. 2016, 50, 9551-9557. [CrossRef] [PubMed]

26. Qiao, G.; Liu, L.; Hao, X.; Zheng, J.; Liu, W.; Gao, J.; Zhang, C.C.; Wang, Q. Signal transduction from small particles: Sulfur nanodots featuring mercury sensing, cell entry mechanism and in vitro tracking performance. Chem. Eng. J. 2020, 382, 122907. [CrossRef]

27. Zhao, L.; Wu, Y.-W.; Han, J.; Wang, H.-X.; Liu, D.-J.; Lu, Q.; Yang, Y.-P. Density Functional Theory Study on Mechanism of Mercury Removal by $\mathrm{CeO}_{2}$ Modified Activated Carbon. Energies 2018, 11, 2872. [CrossRef]

28. Manceau, A.; Merkulova, M.; Murdzek, M.; Batanova, V.; Baran, R.; Glatzel, P.; Saikia, B.K.; Paktunc, D.; Lefticariu, L. Chemical Forms of Mercury in Pyrite: Implications for Predicting Mercury Releases in Acid Mine Drainage Settings. Environ. Sci. Technol. 2018, 52, 10286-10296. [CrossRef]

29. Deng, J.; Li, M.; Wang, Y. Biomass-derived carbon: Synthesis and applications in energy storage and conversion. Green Chem. 2016, 18, 4824-4854. [CrossRef]

30. Wang, W.; Lu, Y.C.; Huang, H.; Wang, A.J.; Chen, J.R.; Feng, J.J. Solvent-free synthesis of sulfur- and nitrogen-co-doped fluorescent carbon nanoparticles from glutathione for highly selective and sensitive detection of mercury(II) ions. Sens. Actuators B Chem. 2014, 202, 741-747. [CrossRef]

31. Ma, J.; Zhou, B.; Zhang, H.; Zhang, W. Fe/S modified sludge-based biochar for tetracycline removal from water. Powd. Technol. 2020, 364, 889-900. [CrossRef]

32. Shin, Y.; Fryxell, G.E.; Um, W.; Parker, K.; Mattigod, S.V.; Skaggs, R. Sulfur-Functionalized Mesoporous Carbon. Adv. Funct. Mater. 2007, 17, 2897-2901. [CrossRef]

33. Marczak-Grzesik, M.; Budzyn, S.; Tora, B.; Szufa, S.; Kogut, K.; Burmistrz, P. Low-cost organic adsorbents for elemental mercury removal from lignite flue gas. Energies 2021, 14, 2174. [CrossRef]

34. Gwenzi, W.; Chaukura, N.; Wenga, T.; Mtisi, M. Biochars as media for air pollution control systems: Contaminant removal, applications and future research directions. Sci. Total Environ. 2021, 753, 142249. [CrossRef]

35. Shen, B.; Li, G.; Wang, F.; Wang, Y.; He, C.; Zhang, M.; Singh, S. Elemental mercury removal by the modified bio-char from medicinal residues. Chem. Eng. J. 2015, 272, 28-37. [CrossRef]

36. Li, G.; Wang, S.; Wang, F.; Wu, Q.; Tang, Y.; Shen, B. Role of inherent active constituents on mercury adsorption capacity of chars from four solid wastes. Chem. Eng. J. 2017, 307, 544-552. [CrossRef]

37. Wang, L.; Chen, M.X.; Yan, Q.Q.; Xu, S.L.; Chu, S.Q.; Chen, P.; Lin, Y.; Liang, H.W. A sulfur-tethering synthesis strategy toward high-loading atomically dispersed noble metal catalysts. Sci. Adv. 2019, 5, 6322. [CrossRef]

38. Wu, Z.Y.; Xu, S.L.; Yan, Q.Q.; Chen, Z.Q.; Ding, Y.W.; Li, C.; Liang, H.W.; Yu, S.H. Transition metal-assisted carbonization of small organic molecules toward functional carbon materials. Sci. Adv. 2018, 4, 0788. [CrossRef]

39. Xu, Y.; Luo, G.; Zhang, Q.; Li, Z.; Zhang, S.; Cui, W. Cost-effective sulfurized sorbents derived from one-step pyrolysis of wood and scrap tire for elemental mercury removal from flue gas. Fuel 2021, 285, 119221. [CrossRef]

40. Shen, B.; Liu, Z.; Xu, H.; Wang, F. Enhancing the absorption of elemental mercury using hydrogen peroxide modified bamboo carbons. Fuel 2019, 235, 878-885. [CrossRef]

41. Yang, J.; Xu, H.; Zhao, Y.; Li, H.; Zhang, J. Mercury Removal from Flue Gas by Noncarbon Sorbents. Energy Fuel 2021, 35, 3581-3610. [CrossRef]

42. Yang, J.; Li, Q.; Zu, H.; Yang, Z.; Qu, W.; Li, M.; Li, H. Surface-engineered sponge decorated with copper selenide for highly efficient gas-phase mercury Immobilization. Environ. Sci. Technol. 2020, 54, 16195-16203. [CrossRef] [PubMed] 
43. Yang, Z.; Yang, J.; Li, H.; Qu, W.; Leng, L.; Zhao, J.; Feng, Y.; Xu, Z.; Liu, H.; Shih, K. Advances in magnetically recyclable remediators for elemental mercury degradation in coal combustion flue gas. J. Mater. Chem. A 2020, 8, 18624-18650. [CrossRef]

44. Yang, J.; Zhao, Y.; Ma, S.; Zhu, B.; Zhang, J.; Zheng, C. Mercury removal by magnetic biochar derived from simultaneous activation and magnetization of sawdust. Environ. Sci. Technol. 2016, 50, 12040-12047. [CrossRef]

45. Revellame, E.D.; Fortela, D.L.; Sharp, W.; Hernandez, R.; Zappi, M.E. Adsorption kinetic modeling using pseudo-first order and pseudo-second order rate laws: A review. Cleaner Eng. Technol. 2020, 1, 100032. [CrossRef]

46. Pichler, C.; Lackner, R. Post-peak decelerating reaction of Portland cement: Monitoring by heat flow calorimetry, modelling by Elovich-Landsberg model and reaction-order model. Constr. Build. Mater. 2020, 231, 117107. [CrossRef]

47. Cabooter, D.; Song, H.; Makey, D.; Sadriaj, D.; Dittmann, M.; Stoll, D.; Desmet, G. Measurement and modelling of the intra-particle diffusion and b-term in reversed-phase liquid chromatography. J. Chromatogr. A 2021, 1637, 461852. [CrossRef]

48. Yang, J.; Li, Q.; Zhu, W.; Qu, W.; Li, M.; Xu, Z.; Yang, Z.; Liu, H.; Li, H. Recyclable chalcopyrite sorbent for mercury removal from coal combustion flue gas. Fuel 2021, 290, 120049. [CrossRef]

49. Cheng, F.; Zhou, P.; Huo, X.; Liu, Y.; Liu, Y.; Zhang, Y. Enhancement of bisphenol A degradation by accelerating the Fe(III)/Fe(II) cycle in graphene oxide modified $\mathrm{Fe}(\mathrm{III}) /$ peroxymonosulfate system under visible light irradiation. J. Colloid Interf. Sci. 2020, 580, 1021. [CrossRef]

50. Feng, P.; Wang, W.; Wang, K.; Cheng, S.; Jiang, K. A high-performance carbon with sulfur doped between interlayers and its sodium storage mechanism as anode material for sodium ion batteries. J. Alloys Compd. 2019, 795, 223-232. [CrossRef]

51. Yu, H.; Qian, C.; Ren, H.; Chen, M.; Tang, D.; Wu, H.; Lv, R. Enhanced catalytic properties of bimetallic sulfides with the assistance of graphene oxide for accelerating triiodide reduction in dye-sensitized solar cells. Sol. Energy 2020, 207, 1037-1044. [CrossRef]

52. Wen, X.; Zhao, Z.; Zhai, S.; Wang, X.; Li, Y. Stable nitrogen and sulfur co-doped carbon dots for selective folate sensing, in vivo imaging and drug delivery. Diam. Relat. Mater. 2020, 105, 107791. [CrossRef]

53. Asasian, N.; Kaghazchi, T.; Faramarzi, A.; Hakimi-Siboni, A.; Asadi-Kesheh, R.; Kavand, M.; Mohtashami, S.-A. Enhanced mercury adsorption capacity by sulfurization of activated carbon with $\mathrm{SO}_{2}$ in a bubbling fluidized bed reactor. J. Taiwan Inst. Chem. E. 2014, 45, 1588-1596. [CrossRef]

54. Guo, Y.; Niu, J.; Zhang, H.; Cheng, F.; Wu, H.; Jin, D. Enhanced $\mathrm{SO}_{2}$ and Rhodamine B Removal by Blending Coke-Making Waste Benzene Residue (BR) for Pelletized Activated Coke (PAC) Production and Mechanisms. Energy Fuel 2019, 33, 5173-5181. [CrossRef]

55. Liu, H.; Xie, X.; Chen, H.; Yang, S.; Liu, C.; Liu, Z.; Yang, Z.; Li, Q.; Yan, X. $\mathrm{SO}_{2}$ promoted ultrafine nano-sulfur dispersion for efficient and stable removal of gaseous elemental mercury. Fuel 2020, 261, 116367. [CrossRef]

56. Zhou, M.; Xie, X.; Liu, Q.; Zhang, M.; Peng, C.; Li, F.; Liu, Q.; Song, Y.; Wu, J.; Qiao, Z. Spherical $\mathrm{In}_{2} \mathrm{~S}_{3}$ anchored on g-C ${ }_{3} \mathrm{~N}_{4}$ nanosheets for efficient elemental mercury removal in the wide temperature range. Chem. Eng. J. 2022, 430, 132857. [CrossRef]

57. Alegre, C.; Sebastián, D.; Lázaro, M.J. Carbon xerogels electrochemical oxidation and correlation with their physico-chemical properties. Carbon 2019, 144, 382-394. [CrossRef]

58. Hsu, C.J.; Chiou, H.J.; Chen, Y.H.; Lin, K.S.; Rood, M.J.; Hsi, H.C. Mercury adsorption and re-emission inhibition from actual WFGD wastewater using sulfur-containing activated carbon. Environ. Res. 2019, 168, 319-328. [CrossRef]

59. Zhao, S.; Luo, H.; Ma, A.; Sun, Z.; Zheng, R. Experimental study on mercury removal from coal-fired flue gas by sulfur modified biomass coke with mechanochemical method. Fuel 2022, 309, 122201. [CrossRef]

60. Yang, Q.; Yang, Z.; Li, H.; Zhao, J.; Yang, J.; Qu, W.; Shih, K. Selenide functionalized natural mineral sulfides as efficient sorbents for elemental mercury capture from coal combustion flue gas. Chem. Eng. J. 2020, 398, 125611. [CrossRef] 